\title{
Penerapan Praktikum dalam Meningkatkan Keterampilan Proses dan Kerja Peserta Didik di Laboratorium IPA
}

\author{
Randa Candra ${ }^{1}$, Dian Hidayati ${ }^{2}$ \\ ${ }^{1,2}$ Pascasarjana Manajemen Pendidikan \\ Universitas Ahmad Dahlan, Yogyakarta, Indonesia \\ ${ }^{1}$ randacandra99@gmail.com,2dian.hidayati@mp.uad.ac.id
}

\begin{abstract}
Practicum activities are an integral part of science learning because practicum will train students' process skills and work skills and effective methods to achieve learning objectives. However, in reality, there are still many students who process expertise, and work skills are still lacking. Therefore, the application of practicum in schools needs to be applied to improve the process skills and work skills of students in the laboratory. The purpose of this study is 1) to know the effect of the application of practicum in increasing students 'process skills, 2) to see the impact of practicum application in increasing students' work skills, 3) the obstacles faced to carry out the practicum. This research is qualitative research with a descriptive approach-data collection techniques with interviews with science teachers. The collected data was analyzed using the Analysis Interactive Model, which included data collection, data display, and verification. The results showed that 1) the effect of practicum in improving process skills in the form of skills in observing, classifying, communicating, measuring, predicting, and concluding 2) the impact of internship in improving process skills in the way of expertise in the use of practicum equipment, 3) Constraints faced when practicum that will hinder the process of students' skills and work skills, namely lack availability of tools and materials, lack of time in practicum implementation, the atmosphere of practicum that is not conducive, the use of laboratories that are not using as a function of science laboratories, and the absence of laboratory assistants. The findings of this study recommend the importance of practicum application in improving the process skills and work skills of students.
\end{abstract}

Kegiatan praktikum merupakan bagian yang tidak dapat dipisahkan dalam pembelajaran IPA, karena dengan adanya praktikum akan melatih keterampilan proses maupun keterampilan kerja peserta didik, serta metode yang efektif dilakukan untuk mencapai tujuan pembelajaran, namun pada kenyatannya masih banyak peserta didik yang keterampilan proses maupun keterampilan kerjanya masih kurang. Oleh sebab itu, penerapan praktikum di sekolah perlu diterapkan untuk meningkatkan keterampilan proses dan keterampilan kerja peserta didik di laboratorium. Tujuan penelitian ini adalah 1) mengetahui pengaruh dari penerapan praktikum dalam meningkatakan 
keterampilan proses peserta didik, 2) mengetahui pengaruh dari penerapan praktikum dalam meningkatakan keterampilan kerja peserta didik, 3) kendala yang dihadapi untuk melaksanakan praktikum. Penelitian ini merupakan peneltian kualitatif dengan pendekatan deskriptif. Teknik pengumpulan data dengan wawancara dengan guru IPA. Data yang terkumpul dianalisis dengan menggunakan Analysis Interactive Model yang meliputi data collection, data display, dan verification. Hasil penelitian menunjukkan bahwa 1) pengaruh praktikum dalam meningkatkan keterampilan proses berupa keterampilan dalam mengamati, mengklasifikasikan, mengkomunikasikan, mengukur, memprediksi, dan menyimpulkan, 2) pengaruh praktikum dalam meningkatkan keterampilan proses berupa keterampilan dalam penggunaan peralatan praktikum, 3) Kendala yang dihadapi pada saat praktikum yang akan menghambat proses keterampilan proses dan keterampilan kerja peserta didik yaitu kurangnya ketersediaan alat dan bahan, kurangnya waktu dalam pelaksanaan praktikum, suasana praktikum yang tidak kondusif, penggunaan laboratorium yang tidak digunakan sebagaimana fungsinya laboratorium IPA, dan tidak adanya laboran. Temuan penelitian ini merekomendasikan tentang pentingnya penerapan praktikum dalam meningkatkan keterampilan proses dan keterampilan kerja peserta didik.

Keywords: Practicum, Process Skills, Work Skills, Laboratory

\section{A. Pendahuluan}

Kriteria minimal sekolah yang bermutu yaitu sekolah yang memiliki fasilitas penunjang pendidikan salah satunya laboratorium dan sekolah yang memiliki sarana dan prasarana yang lengkap dan digunakan sebagaimana mestinya. Hal ini sesuai dengan yang dikemukakan oleh Peraturan Pemerintah (PP) Nomor 19 Tahun 2005 tentang Standar Nasional Pendidikan dikatakan bahwa standar sarana dan prasarana adalah standar nasional pendidikan yang berkaitan dengan kriteria minimal, salah satu fasilitas penunjang pendidikan yang sangat penting adalah adanya laboratorium di sekolah.

Laboratorium digunakan sebagai tempat untuk melakukan percobaan, penelitian atau riset ilmiah yang berhubungan dengan ilmu sains (kimia, fisika, biologi) dan ilmuilmu lainnya. Laboratorium bisa berupa ruangan yang tertutup yang terdiri dari berbagai bagian yang memiliki fungsi masing-masing atau ruangan terbuka seperti kebun, taman, lapangan dan lain-lain. Selain itu pengertian laboratorium yang lain yaitu tempat sekelompok orang yang melakukan berbagai macam kegiatan penelitian (riset), pengamatan, pelatihan dan pengujian ilmiah sebagai pendekatan antara teori dan praktik 
|RANDA CANDRA, DKK.| Penerapan Praktikum dalam Meningkatkan...

dari berbagai macam disiplin ilmu. Secara fisik laboratorium juga dapat merujuk kepada suatu ruangan tertutup, kamar atau ruangan terbuka. ${ }^{1}$

Kegiatan praktikum merupakan bagian yang tidak dapat dipisahkan dalam pembelajaran IPA, karena dengan adanya praktikum akan melatih keterampilan peserta didik baik mulai dari keterampilan melakukan observasi suatu masalah sampai keterampilan dalam mengkomunikasikan hasil riset dalam bentuk laporan kerja dan dengan adanya praktikum, peserta didik akan lebih terampil dalam menggunakan peralatan praktikum yang ada di laboratorium. Selain itu, praktikum dalam pembelajaran IPA merupakan metode efektif yang dilakukan untuk mencapai tujuan pembelajaran. Melalui kegiatan praktikum dapat menjadi wahana belajar pendekatan ilmiah, karena dengan praktikum akan memberikan pengalaman yang sangat menunjang dalam melakukan pendekatan ilmiah, ini disebabkan karena dalam kegiatan praktikum siswa akan diajarkan untuk merumuskan masalah, merancang eksperimen, memakai alat, melakukan pengukuran, menginterpretasi data perolehan, serta mengkomunikasikan dalam bentuk laporan. ${ }^{2}$ Selain itu salah satu metode pembelajaran IPA yang dapat menciptakan kondisi tercapainya hasil konsep keilmuan IPA dan komponen proses keilmuan IPA adalah dengan melaksanakan pembelajaran yang dilakukan di laboratorium berupa praktikum. ${ }^{3}$

Pembelajaran IPA yang efektif menuntut pembelajaran konsep dan sub-konsep yang berfokus pada pengembangan keterampilan proses dan keterampilan kerja. Keterampilan proses terdiri dari: mengamati (observasi), mengkomunikasikan data hasil observasi, menggolongkan (klasifikasi), mengukur, memprediksi, dan menyimpulkan. ${ }^{4}$

Sedangkan untuk keterampilan kerja meliputi keterampilan dalam menggunakan alat dan bahan praktikum, menjaga, dan merawat alat dan bahan praktikum, melakukan praktikum sesuai dengan langkah kerja dan masih banyak lagi. Keterampilan laboratorium penting dimiliki oleh peserta didik karena hal ini akan mempermudah

\footnotetext{
${ }^{1}$ Richard Decaprio, "Tips Mengelola Laboratorium Sekolah” (Yogyakarta: Diva Press, 2013).

${ }^{2}$ Nuryani Rustaman and Dkk, Strategi Belajar Mengajar Biologi (Bandung: Jurusan Pendidikan Biologi FMIPA UPI, 2005).

${ }^{3}$ I.A. Muna, "Optimalisasai Fungsi Laboratorium IPA Melalui Kegiatan Praktikum Pada Prodi PGMI Jurusan Tarbiyah STAIN Ponorogo," Kodifikasia 10, no. 1 (2016).

${ }^{4}$ Maradona, "Analisis Keterampilan Proses Sains Siswa Kelas XI IPA SMA Islam Samarinda Pada Pokok Bahasan Hidrolisis Melalui Metode Eksperimen," Jurnal Pendidikan Ilmiah (2013).
} 
peserta didik memahami pelajaran, memberikan pengalaman langsung. Pendekatan keterampilan laboratorium memberikan pengalaman langsung, pengalaman pertama kepada siswa, sehingga mampu mengubah persepsi siswa tentang hal-hal penting. ${ }^{5}$

Kegiatan praktikum dibedakan menjadi dua yaitu praktikum terbimbing atau terencana dan praktikum bebas. Kegiatan siswa dalam melakukan praktikum terbimbing hanya melakukan percobaan dan menemukan hasilnya saja, seluruh jalannya percobaan sudah dirancang oleh guru. Sedangkan kegiatan peserta didik dalam praktikum bebas lebih banyak dituntut untuk berpikir mandiri, bagaimana merangkai alat percobaan, melakukan percobaan, dan memecahkan masalah, guru hanya memberikan permasalahan dan objek yang harus diamati atau diteliti. ${ }^{6}$

Berdasarkan hasil wawancara dengan guru IPA di SMP Muhammadiyah 3 Depok Sleman Yogyakarta pada Februari 2020 bahwa praktikum sudah dilaksanakan namun terkadang tidak selalu dilakukan di dalam laboratorium, namun terkadang juga dilakukan di dalam kelas. Praktikum dilaksanakan sesuai dengan kebutuhan materi yang disampaikan oleh guru, namun terkadang tidak semua materi bisa dilakukan dengan praktikum ini dikarenakan keadaan peralatan yang kurang mencukupi sehingga tidak mendukung untuk diadakannya suatu praktikum di laboratorium, jadi penyampaian materi hanya menggunakan buku saja. Selain itu, kesulitan yang dialami ketika tidak terlaksananya kegiatan praktikum yaitu kurangnya waktu dan pembiasaan siswa dalam memanfaatkan alat dalam laboratorium untuk membantu memecahkan masalah dinilai kurang. Oleh sebab itu peserta didik akan mengalami kesulitan dalam memahami materi yang guru sampaikan serta peserta didik cenderung kurang terampil dalam mengamati, merumuskan masalah, membuat hipotesis, merancang percobaan, melakukan percobaan, hingga membuat kesimpulan dalam mengkaji fenomena sains yang telah difasilitasi dalam pembelajaran, serta kurang terampil dalam menggunakan peralatan yang sudah disediakan di laboratorium.

Praktikum akan berjalan sebagaimana mestinya apabila ada dukungan dari pihak sekolah dan adanya motivasi dari guru maupun peserta didik dalam melaksanakan praktikum, kelengkapan sarana laboratorium, dan waktu yang cukup untuk

\footnotetext{
${ }^{5}$ Mudjiono \& and Dimyati, Belajar Dan Pembelajaran (Jakarta: Rineka Cipta, 2009).

${ }^{6}$ Paul Suparno, Metodologi Pembelajaran Fisika Konstruktivistik Dan Menyenangkan (Yogyakarta: Universitas Sanata Dharma, 2007).
} 
| RANDA CANDRA, DKK.| Penerapan Praktikum dalam Meningkatkan...

melaksanakan praktikum. Namun pada kenyatannya, kurangnya motivasi dari guru maupun peserta didik dalam melaksankan praktikum, keterbatasan peralatan praktikum, serta kurangnya waktu pelaksanaan kegiatan praktikum akan menghambat keterampilan proses maupun keterampilan kerja dari peserta didik itu sendiri. Karena apabila praktikum tidak berjalan dengan sebagaimana mestinya maka peserta didik akan kesulitan dalam menggunakan peralatan praktikum, kurangnya kemampuan dalam menganalisis dan memecahkan masalah yang ada, dan tidak mengetahui jenis dan fungsi dari peralatan yang digunakan pada saat praktikum.

Oleh sebab itu, penerapan praktikum di setiap sekolah perlu dilakukan, karena dengan adanya praktikum peserta didik lebih bisa berpikir kritis, terampil, paham terhadap materi yang disampaikan, paham cara penggunaan peralatan praktikum yang ada di laboratorium, mendapatkan pengalaman baru, mengkomunikasikan hasil praktikum, mengajukan pertanyaan, dan mampu memecahkan masalah.

Penelitian ini disusun untuk mengetahui: pengaruh dari penerapan praktikum terhadap perkembangan keterampilan proses peserta didik di laboratorium, pengaruh dari penerapan praktikum terhadap perkembanganketerampilan kerja peserta didik, dan kendala yang dihadapi untuk melaksanakan praktikum.

Perbedaan penelitian yang dilakukan sekarang dengan penelitian yang pernah dilakukan oleh Syarifah, ${ }^{7}$ bahwa untuk penelitian terdahulu lebih difokuskan kepada sikap ilmiah peserta didik pada pembelajaran biologi sedangkan penelitian yang akan dilakukan sekarang yaitu difokuskan kepada peningkatan keterampilan proses dan kerterampilan kerja peserta didik di laboratorium.

Penelitian ini menggunakan metode kualitatif. Alasan pemilihan penelitian ini adalah untuk mengeksplorasi pemahaman terkait peranan praktikum terhadap perkembangan keterampilan proses dan kerja peserta didik di laboratorium. Penelitian kualitatif dilakukan untuk mengeksplorasi sebuah subjek. Penelitian ini merupakan rangkaian kegiatan dalam mendapatkan data atau informasi yang bersifat sebenarbenarnya serta memberikan pemahaman menyeluruh dan mendalam mengenai cara guru dalam mengatasi faktor-faktor yang menyebabkan siswa mengalami kesulitan dalam

${ }^{7}$ Syarifah Widya Ulfa, "Pembelajaran Berbasis Praktikum : Upaya Mengembangkan Sikap Ilmiah Siswa Pada Pembelajaran Biologi," Nizmayah VI, no. 1 (2016). 
belajar. ${ }^{8}$ Pendekatan penelitian yang dilakukan berupaya untuk menggambarkan kejadian dan fenomena sesuai dengan apa yang terjadi di lapangan. Dimana data hasil berupa kata-kata tertulis dan lisan dari orang-orang dan perilaku yang dapat diamati. ${ }^{9}$

Penelitian ini dilakukan pada bulan Februari 2020 di SMP Muhammadiyah 3 Depok Sleman Yogyakarta. Subjek dalam penelitian ini adalah guru IPA. Prosedur penelitian ini adalah dengan cara membuat pedoman wawancara yang kemudian melakukan pengambilan data dengan mewawancarai guru IPA terkait peranan praktikum dalam meningkatkan perkembangan keterampilan proses dan kerja peserta didik di laboratorium. Setelah data terkumpul selanjutnya dianalisis menggunakan analysis interactive model. ${ }^{10}$

Teknik analisis data yang dilakukan dalam penelitian ini yaitu: 1) data collection dengan cara menggolongkan, dan membuang data hasil wawancara dan hasil pengamatan yang tidak perlu dan mengorganisasi data sehingga simpulan vinal dapat ditarik dan diverivikasi, 2) data display pada penelitian ini yaitu berbentuk uraian singkat berdasarkan hasil wawancara yang diperkuat dengan hasil pengamatan dari pengembangan karakter peserta didik berkebutuhan khusus, 3) verification. Langkah selanjutnya yaitu penarikan kesimpulan. Penarikan kesimpulan atau verification merupakan kegiatan akhir dari penelitian.

\section{B. Pembahasan}

1. Penerapan Praktikum dalam Meningkatkan Keterampilan Proses Peserta Didik di Laboratorium

Berdasarkan hasil wawancara pada tanggal 12 Februari 2020 dengan guru IPA di SMP Muhammadiyah 3 Depok Sleman Yogyakarta bahwa praktikum sudah dilaksankaan namun belum dilakukan secara maksimal, ini dikarenakan sarana praktikum belum mencukupi, tetapi walaupun belum dilaksanakan secara maksimal peserta didik sudah dibekali sedikit tentang keterampilan proses di laboratorium dengan cara, pada saat praktikum peserta didik dibagi dalam kelompok kecil sehingga hal ini

\footnotetext{
${ }^{8}$ A. Michael Huberman Milles, Mathew B, Qualitative Data Analysis (Terjemahan) (Jakarta:UI Press, 2007).

${ }^{9}$ Ibid.

${ }^{10} \mathrm{Ibid}$.
} 
| RANDA CANDRA, DKK.| Penerapan Praktikum dalam Meningkatkan...

bisa mengatasi keterbatasan peralatan yang kurang mencukupi dan juga bisa meningkatkan keterampilan proses peserta didik melalui kerja sama antar anggota kelompok lainnya dalam memecahkan permasalahan yang sudah diberikan kepada masing-masing kelompok. Karena menurutnya praktikum memang perlu diterapkan dalam membentuk keterampilan proses peserta didik untuk bekal mereka dikemudian hari.

Setelah diterapkan praktikum peserta didik bisa meningkatkan keterampilan proses berupa keterampilan dalam mengamati, mengklasifikasikan, mengkomunikasikan, mengukur, memprediksi, dan menyimpulkan. Peserta didik mampu melakukan pengamatan (observasi) melalui kegiatan mengumpulkan fakta-fakta yang relevan dari lapangan, yang kemudian fakta-fakta tersebut diklasifikasikan atau di kelompokkan dengan jenis-jenisnya, perbedaannya, dan berdasarkan persamaannya, setelah dilakukan pengklasifikasian hasil observasi tersebut selanjutnya dikomunikasikan atau dilakukan diskusi antar anggota kelompok dengan menggambarkan dan membaca data dengan grafik, tabel, atau diagram. Selanjutnya hasil dari diskusi tersebut diukur menggunakan alat bantu. Setelah dilakukan pengukuran selanjutnya dibuat hipotesis atau kemungkinan yang akan terjadi pada hasil penelitian tersebut, apakah hasil tersebut akan valid atau tidak valid. Keterampilan proses yang diperoleh peserta didik pada tahap yang terakhir adalah menyimpulkan, setelah hasil penelitian diperoleh maka hal yang dilakukan selanjutnya adalah menyimpulkan secara tepat dan benar akan hasil yang diperoleh dari penelitian.

Keterampilan proses perlu dimiliki oleh peserta didik karena dengan keterampilan proses bisa meningkatkan kemampuan peserta didik untuk menguasai rangkaian bentuk kegiatan yang berhubungan dengan hasil belajar yang telah dicapai peserta didik, serta mengembangkan kemampuan-kemampuan yang dimiliki oleh peserta didik yang mana prinsip-prinsip dasar tersebut sudah ada dalam diri peserta didik jadi hanya tinggal dikembangkan kemampuan-kemampuannya. Keterampilan proses bertujuan untuk meningkatkan kemampuan peserta didik menyadari, memahami, dan menguasai rangkaian bentuk kegiatan yang berhubungan dengan hasil belajar yang telah dicapai peserta didik. Rangkaian bentuk kegiatan yang dimaksud adalah kegiatan mengamati, menggolongkan, menafsirkan, meramalkan, menerapkan, merencanakan 
penelitian, dan mengkomunikasikan. ${ }^{11}$ Keterampilan proses juga dapat dikatakan sebagai wawasan dalam perkembangan keterampilan-keterampilan intelektual, sosial, dan fisik yang bersumber dari kemampuan-kemampuan mendasar yang prinsipnya telah ada dalam diri peserta didik. ${ }^{12}$ Selain itu, penggunaan keterampilan proses sains, akan memberikan hasil belajar yang lebih permanen. Disamping itu keterampilan proses sains membolehkan siswa memecahkan masalah, berfikir kritis, membuat keputusan, memperoleh jawaban, dan memuaskan keingintahuan mereka. ${ }^{13}$

\section{Penerapan Praktikum dalam Meningkatkan Keterampilan Kerja Peserta Didik di Laboratorium}

Setelah diterapkannya praktikum dalam proses belajar mengajar IPA selain meningkatkan keterampilan proses peserta didik namun juga meningkatkan keterampilan kerja peserta didik di laboratorium. Keterampilan kerja tersebut antara lain peserta didik mampu melakukan perencanaan kegiatan percobaan di laboratorium dengan menentukan alat dan bahan yang akan digunakan pada saat praktikum, menentukan variable, menentukan apa yang harus diamati, diukur, dirubah, ditulis, menentukan cara dan langkah-langkah kerja, serta bisa menentukan bagaimana cara mengolah hasil yang diperoleh pada saat praktikum dilakukan. Selain itu peserta didik juga memiliki keterampilan dalam penggunaan alat laboratorium, fungsi, jenis, dan cara merawatnya supaya bisa digunakan lagi dalam jangka waktu yang panjang. Pembelajaran verbal perlu diimbangi dengan praktikum karena apabila hanya disampaikan melalui pembelajaran verbal saja maka peserta didik akan cepat lupa terkait materi yang sudah dijelaskan oleh guru pada pertemuan sebelumnya, lain halnya apabila diimbangi dengan praktikum maka materi yang disampaikan oleh guru akan bertahan relatif cukup lama karena dengan adanya praktikum akan meningkatkan kemampuan kerja, dan pada akhirnya hasil pembelajaran akan meningkat. Dalam teori belajar disebutkan bahwa tahap dimulai dari penguasaan kemampuan mulai dari mengetahui, memahami dan menguasai. Pembelajaran dengan menggunakan metode

\footnotetext{
${ }^{11}$ Nuryani Rustaman, "Keterampilan Proses Sains" (2007): 1-23.

${ }^{12}$ Moedjiono and Dimyati, Strategi Belajar Mengajar (Jakarta: DEPDIKBUD, 1999).

${ }^{13}$ Et.al Ergul, R., "The Effect of Inquirybasedscienceteaching on Elementary School Students' Science Process Skill and Science Attitudes," Bulgarian Journal of Science and Education Policy (BJSEP) 5, no. 1 (2011): 48-68.
} 
|RANDA CANDRA, DKK.| Penerapan Praktikum dalam Meningkatkan...

verbal dapat membuat peseta didik tahu tetapi cepat lupa. Apabila metode verbal disertai dengan pengamatan, melakukan, peserta didik akan menguasai kemampuan itu dan bertahan relatif lama dalam dirinya. ${ }^{14}$ Pembelajaran sains menekankan pada pemberian pengalaman belajar secara langsung melalui penggunaan dan pengembangan keterampilan proses dan kerja ilmiah. Kegiatan praktikum menunjang materi pembelajaran. Dengan praktikum memberikan kesempatan bagi siswa untuk menemukan teori atau membuktikan teori. ${ }^{15}$

\section{Kendala yang Dihadapi pada Saat Praktikum}

Kendala yang dihadapi pada saat praktikum yang akan menghambat proses keterampilan proses dan keterampilan kerja peserta didik yaitu kurangnya ketersediaan alat dan bahan, kurangnya waktu dalam pelaksanaan praktikum, suasana praktikum yang tidak kondusif, penggunaan laboratorium yang tidak digunakan sebagaimana fungsinya laboratorium IPA, dan tidak adanya laboran. Hambatan dalam melakukan kegiatan laboratorium yaitu selain tidak adanya tenaga laboran atau teknisi laboratorium, masih kurangnya pemahaman guru tentang pentingnya inovasi dalam pembelajaran untuk mengembangkan kebiasaan keterampilan berpikir kritis dan mengembangkan kebiasaan berpikir ilmiah. Dalam pendidikan sains, masih terdapat ruang laboratorium yang digunakan sebagai tempat belajar, bahkan ruang laboratorium fisika masih ada juga yang bergabung dengan ruang laboratorium kimia dan biologi, tidak cukup waktu untuk melaksanakan praktikum dengan memanfaatkan alat atau fasilitas yang ada. ${ }^{16}$

Kurangnya alat dan bahan untuk praktikum di laboratorium menyebabkan peserta didik harus menggunakan peralatan secara bergantian, hal ini disebabkan karena kurangnya anggaran untuk pengadaan sarana praktikum tersebut sehingga hal ini akan menghambat keterampilan peserta didik dan menghambat proses pembelajaran secara praktikum.

\footnotetext{
${ }^{14}$ Sitepu, Pengembangan Sumber Belajar (Jakarta: Rajawali Press, 2014).

${ }^{15}$ Amna Emda, "Laboratorium Sebagai Sarana Pembelajaran Kimia Dalam Meningkatkan Pengetahuan Dan Ketrampilan Kerja Ilmiah,” Lantanida Journal 5, no. 1 (2017): 83.

${ }^{16}$ Sundoro, "Analisi Sarana Dan Intensitas Penggunaan Laboratorium Fisika Serta Kontribusinya Terhadap Hasil Belajar Siswa SMA Negeri Di Kabupaten Jembrana," E- Journal Program Pascasarjana Universitas Pendidikan Ganesha 3 (2013).
} 
Kemudian kurangnya waktu dalam pelaksanaan praktikum sering dialami oleh guru dan praktikan ketika sedang praktikum, hal ini disebabkan karena praktikum memang membutuhkan waktu yang cukup banyak dalam pengerjaan setiap langkah kerjanya dan satu praktikum harus selesai dalam satu kali pertemuan. Apabila praktikum tidak selesai dalam satu kali pertemuan maka akan menyebabkan peserta didik bingung akan hasil yang didapatkan sehingga akan menghambat peningkatan keterampilan proses peserta didik di laboratorium.

Suasana praktikum yang tidak kondusif. Hal ini dikarenakan peserta didik yang terlalu bersemangat dalam mengikuti kegiatan praktikum sehingga mereka asik melakukan kegiatan mereka sendiri tanpa memperhatikan penjelasan tentang cara-cara penggunaan alat, fungsinya, dan langkah kerja dalam praktikum. Kegiatan praktikum harus dilaksanakan dengan santai namun serius dan kondusif karena akan membantu peserta didik fokus terhadap materi yang disampaikan guru dan bisa meningkatkan keterampilan proses dan keterampilan kerja peserta didik.

Penggunaan laboratorium yang tidak digunakan sebagaimana fungsinya, karena selain digunakan sebagai tempat praktikum, juga dimanfaatkan untuk kegiatan ekstrakulikuler, dan rapat sekolah, hal inilah yang akan menyebabkan terhambatnya kegiatan praktikum di laboratorium yang seharusnya pada hari yang sama dan jam sama ada kegiatan praktikum tetapi digunakan untuk kegiatan lain maka kegiatan praktikum harus ditunda diminggu selanjutnya. Hal ini juga yang menyebabkan terhambatnya keterampilan proses dan keterampilan kerja peserta didik.

Selanjutnya, tidak adanya laboran. Hal ini menyebabkan peralatan praktikum tidak dirawat secara berkala sehingga tidak bisa digunakan dalam jangka waktu yang panjang dan akan menghambat proses pembelajaran yang seharunya diimbangi dengan kegiatan praktikum. praktikum tidak terlaksana maka akan menghambat proses peningkatan keterampilan peserta didik baik itu keterampilan proses maupun keterampilan kerja. Peralatan praktikum harus dirawat secara berkala sehingga bisa digunakan dalam jangka waktu yang panjang.

Berdasarkan beberapa pernyataan di atas dapat diketahui bahwa praktikum perlu diterapkan dan memiliki peranan penting untuk menyeimbangi materi dan meningkatkan keterampilan proses dan keterampilan kerja peserta didik. Sains di 
| RANDA CANDRA, DKK.| Penerapan Praktikum dalam Meningkatkan...

laboratorium dimaksudkan untuk memberikan pengalaman memanipulasi berbagai peralatan dan bahan laboratorium dan juga membantu siswa untuk pengembangan pemahaman konseptual. ${ }^{17}$

\section{Penutup}

Hasil analisis dan diskusi penelitian menunjukkan bahwa setelah diterapkannya praktikum peserta didik bisa meningkatkan keterampilan proses berupa keterampilan dalam mengamati, mengklasifikasikan, mengkomunikasikan, mengukur, memprediksi, dan menyimpulkan. Selain meningkatkan keterampilan proses juga meningatkan keterampilan kerja yakni mampu melakukan perencanaan kegiatan percobaan dengan menentukan alat dan bahan yang akan digunakan, menentukan variable, menentukan apa yang harus diamati, diukur, dirubah, ditulis, menentukan cara, dan langkah-langkah kerja, serta bisa menentukan bagaimana cara mengolah hasil yang diperoleh, mampu menggunakan alat laboratorium, fungsi, jenis, dan cara merawatnya supaya bisa digunakan lagi dalam jangka waktu yang panjang. Serta kendala yang dihadapi pada saat praktikum yang akan menghambat proses keterampilan proses dan keterampilan kerja peserta didik yaitu kurangnya ketersediaan alat dan bahan, kurangnya waktu dalam pelaksanaan praktikum, suasana praktikum yang tidak kondusif, penggunaan laboratorium yang tidak digunakan sebagaimana fungsinya laboratorium IPA, dan tidak adanya laboran

${ }^{17} \mathrm{R}$ Trumper, "What Do We Expect from Students' Physics Laboratory Experiments?," Journal of Science Education and Technology 11, no. 3 (2002): 221-228. 


\section{DAFTAR PUSTAKA}

Decaprio, Richard. “Tips Mengelola Laboratorium Sekolah.” Yogyakarta: Diva Press, 2013.

Emda, Amna. "Laboratorium Sebagai Sarana Pembelajaran Kimia Dalam Meningkatkan Pengetahuan Dan Ketrampilan Kerja Ilmiah.” Lantanida Journal 5, no. 1 (2017): 83.

Ergul, R., Et.al. "The Effect of Inquirybasedscienceteaching on Elementary School Students' Science Process Skill and Science Attitudes." Bulgarian Journal of Science and Education Policy (BJSEP) 5, no. 1 (2011): 48-68.

Maradona. "Analisis Keterampilan Proses Sains Siswa Kelas XI IPA SMA Islam Samarinda Pada Pokok Bahasan Hidrolisis Melalui Metode Eksperimen.” Jurnal Pendidikan Ilmiah (2013).

Milles, Mathew B, A. Michael Huberman. Qualitative Data Analysis (Terjemahan). Jakarta: UI Press, 2007.

Moedjiono, and Dimyati. Strategi Belajar Mengajar. Jakarta: DEPDIKBUD, 1999.

Mudjiono \&, and Dimyati. Belajar Dan Pembelajaran. Jakarta: Rineka Cipta, 2009.

Muna, I.A. "Optimalisasai Fungsi Laboratorium IPA Melalui Kegiatan Praktikum Pada Prodi PGMI Jurusan Tarbiyah STAIN Ponorogo.” Kodifikasia 10, no. 1 (2016).

Rustaman, Nuryani. "Keterampilan Proses Sains" (2007): 1-23.

Rustaman, Nuryani, and Dkk. Strategi Belajar Mengajar Biologi. Bandung: Jurusan Pendidikan Biologi FMIPA UPI, 2005.

Sitepu. Pengembangan Sumber Belajar. Jakarta: Rajawali Press, 2014.

Sundoro. "Analisi Sarana Dan Intensitas Penggunaan Laboratorium Fisika Serta Kontribusinya Terhadap Hasil Belajar Siswa SMA Negeri Di Kabupaten Jembrana." E- Journal Program Pascasarjana Universitas Pendidikan Ganesha 3 (2013).

Suparno, Paul. Metodologi Pembelajaran Fisika Konstruktivistik Dan Menyenangkan. Yogyakarta: Universitas Sanata Dharma, 2007.

Trumper, R. "What Do We Expect from Students' Physics Laboratory Experiments?" Journal of Science Education and Technology 11, no. 3 (2002): 221-228.

Ulfa, Syarifah Widya. "Pembelajaran Berbasis Praktikum: Upaya Mengembangkan Sikap Ilmiah Siswa Pada Pembelajaran Biologi.” Nizmayah VI, no. 1 (2016). 